DOI: $10.15593 / 2499-9873 / 2020.1 .07$

УДК 519.7

\title{
Т.А. Катаева
}

Пермская научно-производственная приборостроительная компания, Пермь, Россия

Пермский национальный исследовательский политехнический университет, Пермь, Россия

\section{ПРИМЕНЕНИЕ МЕХАНИЗМА КОМПЛЕКСНОГО ОЦЕНИВАНИЯ К РЕШЕНИЮ ЗАДАЧИ ОТБОРА ПРОЕКТА}

\begin{abstract}
Описывается модель сложной организационной системы управления, в рамках которой одновременно реализуется несколько подходов: функциональный, процессный и проектный. Обосновывается актуальность применения механизмов комплексного оценивания к задачам управления в организационных системах, в частности к решению задач согласованного принятия решений. Описываются причины несогласованности интересов в процессе принятия решений. Приводятся примеры задач управления в организационных системах. Детально рассматривается пример решения задачи отбора проектов в портфель с помощью механизма комплексного оценивания. Приводится совокупность критериев оценки и описываются матрицы свертки, которые получаются в результате парных сравнений показателей. Предлагается дальнейший план развития механизма оценки проекта по трем уровням, включая оценку рисков, с учетом ранга эксперта.

Ключевые слова: организационная система, матричная структура, согласование интересов, бизнес-процессы, проекты, задача многокритериального выбора, критерии отбора проекта, дерево критериев, матричные свертки, механизм комплексного оценивания.
\end{abstract}

\section{T.A. Kataeva}

Perm Scientific-Industrial Instrument Making Company, Perm, Russian Federation Perm National Research Polytechnic University, Perm, Russian Federation

\section{THE INTEGRATED RATING MECHANISM APPLICATION TO THE DECISION OF THE PROJECT SELECTION PROBLEM}

The article describes the model of a complex organizational management system where the several approaches are simultaneously implementing: functional, process and design. The relevance of applying integrated assessment mechanisms to management tasks in organizational systems, in particular, to solving the problems of coordinated decision-making, is substantiated. The reasons for the inconsistency of interests in the decision-making process are described. Examples of management tasks in organizational systems are given. The example of solving the problem of selecting projects into a portfolio using the integrated assessment mechanism is considered in detail. A set of evaluation criteria is given and convolution matrices are described. The development plan for the project assessment mechanism including risk assessment, taking into account the rank of expert is proposed.

Keywords: organizational system, matrix structure, coordination of interests, businessprocesses, projects, multicriteria decision making, project selection criteria, tree of criteria, matrix convolutions, rating and control mechanism. 


\section{Introduction}

Due to the continuous change in the external environment and high uncertainty, real business needs a decision-making tool that satisfies several conditions: flexible, fast in calculations, understandable to the user and multi-factor. To make a decision is to choose one from many alternatives. To make a choice, you must evaluate each alternative. The different rating and control mechanisms cope for this task.

Currently, most of the procedures at the lower levels of management are subject to automation; at this level, the machine can make a decision. However, complex decisions beyond the limits of one function department made by a person or even a group of interested persons. Thus, decisionmaking in the organizational system involves the need to coordinate the interests of the interacting parties [1]. Especially, this applies to companies with a complex matrix structure, high-tech production. Such companies has the complex processes that are not standardized and constantly changing.

\section{An Example of the Practical Application of the Matrix Mechanism to Control Problems}

Consider the organizational system where the functional structure officially operates, process approach is introduced and project activities are carried out in parallel (Fig. 1). In this case, the organizational structure has a matrix form. The matrix structure is characterized by double subordination. At the intersections of structures, problems of coordination of interests arise.

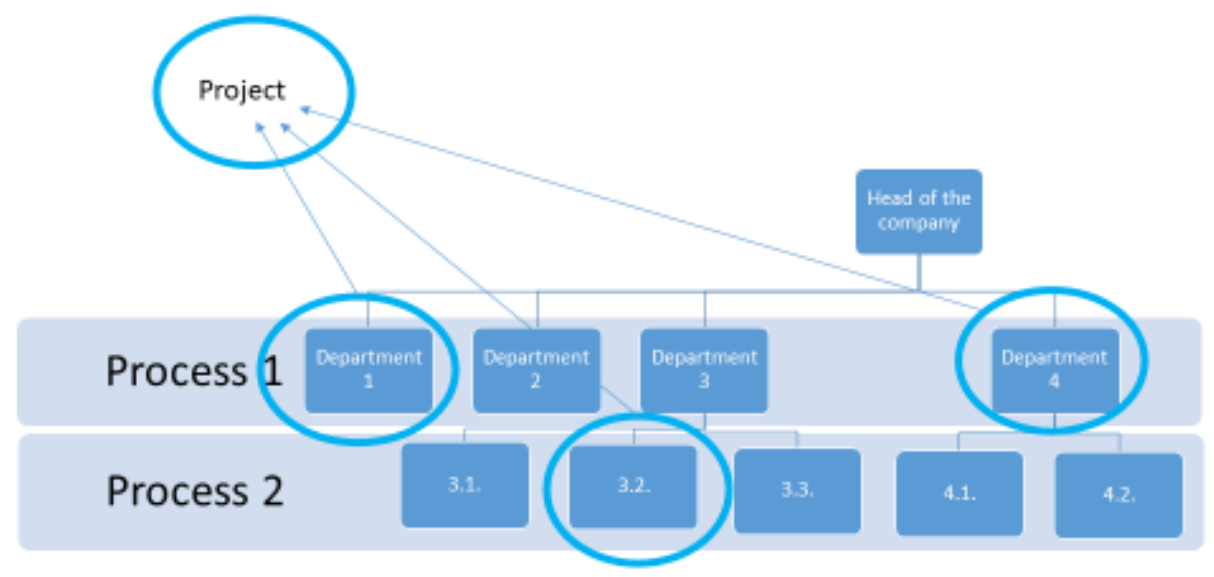

Fig. 1. Organizational structure model 
Coordination of interests in structures of this type falls between representatives of several roles: the owner of the process, the head of the functional unit (department), and the project manager. They are the decision makers (decision makers).

Table 1 shows the examples of management tasks that arise during the interactions of various roles in the organizational system.

Table 1

Examples of practical control problems in complex matrix structures

\begin{tabular}{|c|c|c|}
\hline No & Management task & Brief \\
\hline 1 & $\begin{array}{l}\text { Decision-making on } \\
\text { project implementation }\end{array}$ & $\begin{array}{l}\text { The task is to conduct an assessment of activities on } \\
\text { the subject of "design", allows you to choose activi- } \\
\text { ties that are effectively implemented within the pro- } \\
\text { ject. The question is being solved: "what is the pro- } \\
\text { ject?" }\end{array}$ \\
\hline 2 & $\begin{array}{l}\text { Project portfolio } \\
\text { performance } \\
\text { Assessment }\end{array}$ & $\begin{array}{l}\text { The task is to evaluate the effectiveness of both a sin- } \\
\text { gle project and the project portfolio as a whole. It is } \\
\text { necessary to determine the evaluation indicators, es- } \\
\text { tablish the priority of projects }\end{array}$ \\
\hline 3 & Process evaluation & $\begin{array}{l}\text { The solution of the problem should be based on eval- } \\
\text { uating the effectiveness of a single function per- } \\
\text { formed in the process. If the organization has func- } \\
\text { tional and a process structure at the same time, then } \\
\text { the process will often performed by specialists from } \\
\text { various functional units, which leaves its mark on the } \\
\text { execution of the process }\end{array}$ \\
\hline 4 & $\begin{array}{l}\text { Assessment of the de- } \\
\text { gree of implementation } \\
\text { of methodologies (Lean, } \\
\text { QRM, ISO, etc.) }\end{array}$ & $\begin{array}{l}\text { The solution to the problem is achieved by developing } \\
\text { a questionnaire, conducting a survey, and convolving } \\
\text { estimates into a comprehensive indicator }\end{array}$ \\
\hline 5 & $\begin{array}{l}\text { Assessment of the ef- } \\
\text { fectiveness of the or- } \\
\text { ganizational system as } \\
\text { a whole }\end{array}$ & $\begin{array}{l}\text { It consists in developing a system of indicators that } \\
\text { assesses the management system as a whole, how } \\
\text { well it is agreed and effective. }\end{array}$ \\
\hline 6 & Staff assessment & $\begin{array}{l}\text { In the framework of the competency-based approach, } \\
\text { it is necessary to determine the matrix of competen- } \\
\text { cies, then evaluate each person on the basis of the se- } \\
\text { lected criteria. }\end{array}$ \\
\hline 7 & Risk-manag & $\begin{array}{l}\text { Identification, analysis and assessment of risks, etc. } \\
\text { Requires coordination of interests of interested parties }\end{array}$ \\
\hline
\end{tabular}


These tasks can be solved using rating and control mechanisms. As an example, consider the first task from table 1, because the participant decision-making problem for any high technology companies such as Perm Scientific-Industrial Instrument Making Company is research and development (R\&D) project selection.

This problem investigates by some authors, for example [2-5], there are discusses the list of criteria, their importance, methods and approaches allowing to make into account all the criteria in the complex when choosing R\&D project. For example, the papers [3,4] proposes to use analytic hierarchy process. However, some papers, for example, [6-7] shows, that applying the analytic hierarchy process may lead to mistaken conclusions. If the value of $R \& D$ projects will be consider, then the other methods must be applied to solve the problem.

The paper [8] investigates the effectiveness the application of methods of the theory of the criteria importance in hierarchical problems of multicriteria decision making. Speaking about hierarchical methods for solving multi-criteria decision-making problems, the well-know methods matrix rating and control mechanisms should be mentioned. A description of these mechanisms is not gives in this paper; they can be found in other article [9-16].

The matrix rating and control mechanisms make possible to take into account the opinions of few agents [15] and coordinate their interests.

Moreover known several programs are called "Dekon" [11, 12] cope for application this methods and mechanism in different fields and scope. With the participation of the author was developed special module in the program "Research of Dynamic Systems" [16].

All said above determined the choice of methods applicable for solving the $R \& D$ project selection problem in favor of matrix rating mechanisms. In this paper will be shown set of criteria for R\&D project selection, hierarchy tree of criteria and set of convolution matrices. They ones together are defining integrated rating mechanism for the project selection.

Fig. 2 shows the criteria that were selected by a group of experts in the first stage. The experts were consisted of the heads of company departments. The purpose of the first stage is to decide whether any activity is a project. There are three possible solutions: an activity is executed as a project $(\mathrm{P})$, an activity can be issued as a project (IBE), an activity is not a project (NP). 


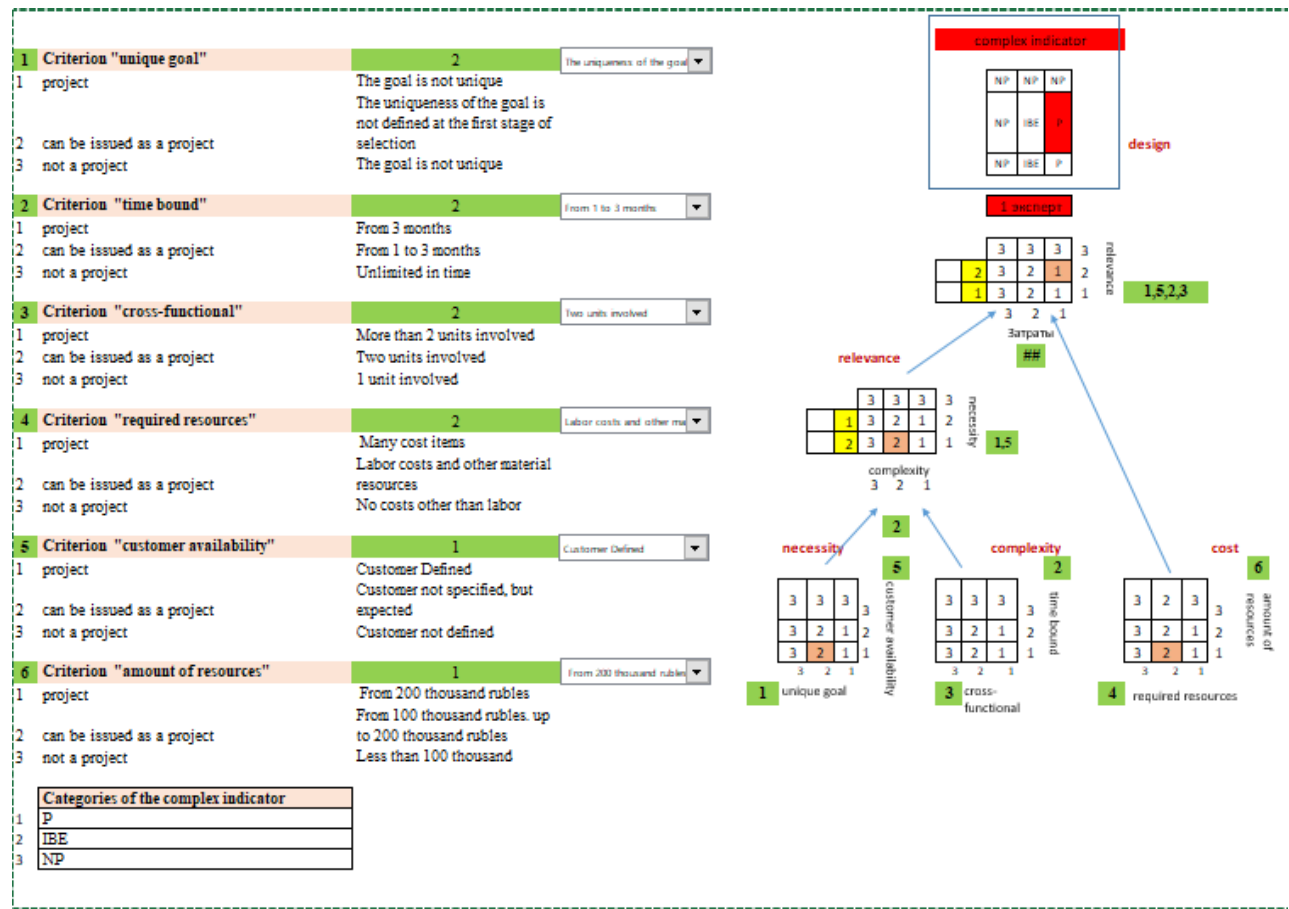

Fig. 2. The matrix mechanism of integrated project evaluation

The criteria tree is formed by six indicators that are involved in pairwise comparisons: "unique goal", "time bound", "cross-functional", "required resources", "customer availability", "amount of resources". The indicators "unique goal" and "customer availability", "cross-functional" and "time bound", "required resources" and "amount of resources" are compared among themselves. Each indicator is assigned values from 1 to 3 (Table 2), which forms matrices of the corresponding dimension, $3 \times 3$ (see Fig. 2).

Table 2

Project Evaluation Criteria

\begin{tabular}{|c|l|l|}
\hline No & \multicolumn{1}{|c|}{ Criteria } & \multicolumn{1}{|c|}{ Values } \\
\hline 1 & $\begin{array}{l}\text { The existence of } \\
\text { unique purpose }\end{array}$ & $\begin{array}{l}\text { 1- The goal is not unique } \\
\text { 2- The uniqueness of the goal is not defined at the first } \\
\text { stage of selection } \\
\text { 3- The goal is not unique }\end{array}$ \\
\hline 2 & Time bound & $\begin{array}{l}\text { 1- From 3 months } \\
\text { 2- From 1 to 3 months } \\
\text { 3- Unlimited in time }\end{array}$ \\
\hline 3 & Cross-functional & $\begin{array}{l}\text { 1- More than 2 units involved } \\
\text { 2- Two units involved } \\
\text { 3- 1 unit involved }\end{array}$ \\
\hline
\end{tabular}


End of Table 2

\begin{tabular}{|c|l|l|}
\hline No & \multicolumn{1}{|c|}{ Criteria } & \multicolumn{1}{c|}{ Values } \\
\hline 4 & $\begin{array}{l}\text { Required } \\
\text { resources }\end{array}$ & $\begin{array}{l}\text { 1- Many cost items } \\
\text { 2- Labor costs and other material resources } \\
\text { 3- No costs other than labor }\end{array}$ \\
\hline 5 & $\begin{array}{l}\text { Customer } \\
\text { availability }\end{array}$ & $\begin{array}{l}\text { 1- Customer Defined } \\
\text { 2- Customer not specified, but expected } \\
\text { 3- Customer not defined }\end{array}$ \\
\hline 6 & $\begin{array}{l}\text { Amount of } \\
\text { resources }\end{array}$ & $\begin{array}{l}\text { 1- From 200 thousand rubles. } \\
\text { 2- From 100 thousand rubles up to 200 thousand rubles. } \\
\text { 3- Less than 100 thousand rubles. }\end{array}$ \\
\hline
\end{tabular}

Based on Table 2, a pairwise comparison is carried out. Then convolution matrices are calculated, which ultimately gives a comprehensive assessment of the activity.

\section{Conclusion}

Thus, the use of the matrix mechanisms for integrated assessment allows us to solve a number of important practical problems. The example of integrated project evaluation, presented in this article, proves the applicability of the mechanism to real tasks. The evaluation mechanism can be used in other companies, since the criteria are multipurpose, they allow you to separate the project from the process. It is necessary to adapt the values in the convolution matrices to use this mechanism. A comprehensive assessment allows to managers make a decision about the starting of a project.

The next stages of investigation:

- description of the mechanism for the formation and evaluation of the project portfolio based on the matrix mechanism of integrated assessment;

- development of a comprehensive project risk assessment mechanism;

- development of a mechanism for calculating the motivation of project participants based on a comprehensive assessment of project effectiveness.

\section{Список литературы}

1. Катаева Т.А. Содержательная постановка задачи согласования интересов агентов в организационной иерархии // XIII Всероссийское совещание по проблемам управления (ВСПУ-2019), г. Москва, 17-20 июня 2019 г. / Ин-т пробл. упр-я им. В.А. Трапезникова РАН, Москва, 17-20 июня 2019 г. М.: ИПУ РАН. - С. 2304-2309. 
2. Henriksen A.D., Traynor A.J. A practical R\&D project-selection scoring tool // IEEE Transactions on Engineering Management. - 1999. - Vol. 46, iss.2. P. 158-170. DOI: 10.1109/17.759144

3. Meade L.M., Presley A. R\&D project selection using the analytic network process // IEEE Transactions on Engineering Management. - 2002. - Vol. 49, iss. 1. - P. 59-66. DOI: 10.1109/17.985748

4. Lee J.W., Kim S.H. Using analytic network process and goal programming for interdependent information system project selection // Computers \& Operations Research. - 2000. - Vol. 27, iss. 4. - P. 367-382. DOI: 10.1016/S0305-0548(99)00057-X

5. Lee J.W., Kim S.H. An integrated approach for interdependent information system project selection // International Journal of Project Management. 2001. - Vol. 19, iss. 2. - P. 111-118. DOI: 10.1016/S0263-7863(99)00053-8

6. Подиновский В.В., Подиновская О.В. О некорректности метода анализа иерархий // Проблемы управления. - 2011. - № 1. - С. 8-13.

7. Подиновский В.В., Подиновская О.В. Еще раз о некорректности метода анализа иерархий // Проблемы управления. - 2012. - № 4. - С. 75-78.

8. Подиновская О.В., Подиновский В.В. Анализ иерархических многокритериальных задач принятия решений методами теории важности критериев // Проблемы управления. - 2014. - № 6. - С. 2-8.

9. Бурков В.Н., Новиков Д.А. Как управлять проектами: науч.-практ. изд. - М.: Синтег-ГЕО, 1997. - 190 с.

10. Курочка П.Н. Моделирование задач организационно-технологического проектирования / ВГАСУ. - Воронеж, 2004. - 204 с.

11. Харитонов В.А., Винокур И.Р., Белых А.А. Функциональные возможности механизмов комплексного оценивания с топологической интерпретацией матриц свертки // Управление большими системами: сб. тр. - 2007. Вып. 18. - С.129-140.

12. Харитонов В.А., Винокур И.Р., Белых А.А. Современные технологии комплексного оценивания научно-технических проектов // Космический вызов XXI века. Новые материалы и технологии для ракетнокомической техники: мат. междунар. шк.-конф. (SPACE-2006), г. Севастополь, 23-30 сентября 2006 г. / Ин-т хим. физ. им. Н.Н. Семенова РАН. - M., 2007. - T. 3. - C. 429-433.

13. Алексеев А.О. Классификация механизмов комплексного оценивания сложных объектов // Информационные и математические методы в науке и управлении. - 2018. - № 2 (10). - С. 114-120.

14. Алексеев А.О. Комплексное оценивание сложных объектов в условиях неопределенности // Прикладная математика и вопросы управления. 2019. - № 2. - C. 103-131. 
15. Алексеев А.О. Исследование устойчивости механизмов комплексного оценивания к стратегическому поведению агентов (на примере согласования политики организации в области риск-менеджмента) // Прикладная математика и вопросы управления. - 2019. - № 4. - С. 136-154.

16. Alekseev A., Salamatina A., Kataeva T. Rating and control mechanisms design in the program "Research of Dynamic Systems" // 21st IEEE Conference on Business Informatics, Moscow, 15-17 July 2019: Proceedings: in 2 vol. Vol. 2. Research-in-Progress Papers and Workshop Papers / Inst. of Electrical and Electronics Eng. (IEEE). - Los Alamitos, California; Washington; Tokyo: IEEE Computer Soc. Conf. Publ. Services (CPS), 2019. - P. 96-105. DOI 10.1109/CBI.2019.10103

\section{References}

1. Kataeva T.A. Soderzhatel'naia postanovka zadachi soglasovaniia interesov agentov v organizatsionnoi ierarkhii [Statement of the the agent's interests coordinating problem in the organizational hierarchy]. XIII All-Russian meeting on control problems, 17-20 June 2019, Moscow, V.A. Trapeznikov Control Sciences Institute of Russian Academy of Sciences, 2019, pp. 2304-2309.

2. Henriksen A.D., Traynor A.J. A practical R\&D project-selection scoring tool. IEEE Transactions on Engineering Management, 1999, vol. 46, iss. 2, pp. 158-170, DOI: 10.1109/17.759144

3. Meade L.M., Presley A. R\&D project selection using the analytic network process. IEEE Transactions on Engineering Management, 2002, vol. 49, iss. 1, pp. 59-66, DOI: 10.1109/17.985748

4. Lee J.W., Kim S.H. Using analytic network process and goal programming for interdependent information system project selection. Computers \& $\mathrm{Op}$ erations Research, 2000, vol. 27, iss. 4, pp. 367-382, DOI: 10.1016/S03050548(99)00057-X

5. Lee J.W., Kim S.H. An integrated approach for interdependent information system project selection. International Journal of Project Management, 2001, vol. 19, iss. 2, pp. 111-118, DOI: 10.1016/S0263-7863(99)00053-8

6. Podinovskii V.V., Podinovskaia O.V. O nekorrektnosti metoda analiza ierarkhii [On the theoretical incorrectness of the analytic hierarchy process]. Control Sciences, 2011, no. 1, pp. 8-13.

7. Podinovskii V.V., Podinovskaia O.V. Eshche raz o nekorrektnosti metoda analiza ierarkhii [Again on the theoretical incorrectness of the analytic hierarchy process]. Control Sciences, 2012, no. 4, pp. 75-78.

8. Podinovskaia O.V., Podinovskii V.V. Analiz ierarkhicheskikh mnogokriterial'nykh zadach priniatiia reshenii metodami teorii vazhnosti kriteriev [Analysis of hierarchical multi-criterion decision making problems by using the methods of the criteria importance theory]. Control Sciences, 2014, no. 6, pp. 2-8. 
9. Burkov V.N., Novikov D.A. Kak upravliat' proektami [How to manage of a projects]. Moscow, Sinteg, 1997, 190 p.

10. Kurochka P.N. Modelirovanie zadach organizatsionno-tekhnologicheskogo proektirovaniia [Modeling of organizational and technological design tasks]. Voronezh, Voronezh State Architecture and Construction University, 2004, 204 p.

11. Kharitonov V.A., Vinokur I.R., Belykh A.A. Funktsional'nye vozmozhnosti mekhanizmov kompleksnogo otsenivaniia $\mathrm{s}$ topologicheskoi interpretatsiei matrits svertki [Functionality of integrated assessment mechanisms with topological interpretation of convolution matrices]. Large-Scale Systems Control, 2007, vol. 18, pp. 129-140.

12. Kharitonov V.A., Vinokur I.R., Belykh A.A. Sovremennye tekhnologii kompleksnogo otsenivaniia nauchno-tekhnicheskikh proektov [Actual rating and control technologies of the R\&D project]. The space challenge of the 21st century. New materials and technologies for rocket-comic equipment, proceedings of international conference SPACE - 2006 (September, 23-30, 2006, Sevastopol). Vol. 3, Moscow, Semenov Institute of Chemical Physics Russian Academy of Sciences, 2007, pp. 429-433.

13. Alekseev A.O. Klassifikatsiia mekhanizmov kompleksnogo otsenivaniia slozhnykh ob"ektov [Classification of integrated assessment mechanisms for complex objects]. Information and mathematical technologies in science and management, 2018, no. 2 (10), pp. 114-120.

14. Alekseev A.O. Kompleksnoe otsenivanie slozhnykh ob"ektov v usloviiakh neopredelennosti [Rating and control of complex objects in uncertainty cases]. Applied Mathematics and Control Sciences, 2019, no. 2, pp. 103-131.

15. Alekseev A.O. Issledovanie ustoichivosti mekhanizmov kompleksnogo otsenivaniia $\mathrm{k}$ strategicheskomu povedeniiu agentov (na primere soglasovaniia politiki organizatsii v oblasti risk-menedzhmenta) [Stability analysis of the rating and control mechanism to agent's strategic behavior (on example of the risk management policy coordination)]. Applied Mathematics and Control Sciences, 2019. no. 4, pp. 136-154.

16. Alekseev A., Salamatina A., Kataeva T. Rating and Control Mechanisms Design in the Program "Research of Dynamic Systems". 21st IEEE Conference on Business Informatics Proceedings. In 2 vol. Vol. 2: Research-in-Progress Papers and Workshop Papers, 2019, vol. 2, pp. 96-105, DOI 10.1109/CBI.2019.10103

Получено 20.10.2019

Принято 30.01.2020 


\section{Сведения об авторе}

Катаева Татьяна Александровна (Пермь, Россия) - начальник бюро управления проектами, ПАО «Пермская научно-производственная приборостроительная компания»; аспирант кафедры «Строительный инжиниринг и материаловедение», Пермский национальный исследовательский политехнический университет (614990, Пермь, Комсомольский пр., 29, e-mail: tatyana.kataeva2014@yandex.ru).

\section{About the author}

Tatiana A. Kataeva (Perm, Russian Federation) - Head of Project Management. Perm Scientific-Industrial Instrument Making Company, Ph.D. Student, Department of Construction Engineering and Materials Science, Perm National Research Polytechnic University (614990, Perm, Komsomolsky av., 29, e-mail: tatyana.kataeva2014@yandex.ru).

Библиографическое описание статьи согласно ГОСТ Р 7.0.100-2018:

Катаева, Т. А. Применение механизма комплексного оценивания к решению задачи отбора проекта $=$ The integrated rating mechanism application to the decision of the project selection problem / T. А. Катаева. - DOI 10.15593/2499-9873/2020.1.07. Текст : непосредственный // Прикладная математика и вопросы управления = Applied Mathematics and Control Sciences . - 2020. - № 2. - С. 104. -113. - Ст. на англ. языке.

\section{Цитирование статьи в изданиях РИНЦ:}

Катаева Т.А. Применение механизма комплексного оценивания к решению задачи отбора проекта // Прикладная математика и вопросы управления. - 2020. - № 1. C. 104-113. DOI: 10.15593/2499-9873/2020.1.07

\section{Цитирование статьи в references и международных изданиях:}

\section{Cite this article as:}

Kataeva T.A. The integrated rating mechanism application to the decision of the project selection problem. Applied Mathematics and Control Sciences, 2020, no. 1, pp. 104-113. DOI: 10.15593/2499-9873/2020.1.07 (in English) 